\title{
THEORETICAL ASPECTS OF INNOVATION IN HEALTH TOURISM
}

\author{
ALEKSANDER PANASIUK \\ Jagiellonian University, Faculty of Management and Social Communication, Institute of Entrepreneurship, \\ Entrepreneurship in Tourism Department, POLAND \\ e-mail: aleksander.panasiuk@uj.edu.pl
}

\begin{abstract}
RECEIVED
ACCEPTED

JEL

CLASSIFICATION
\end{abstract}

KEYWORDS

ABSTRACT

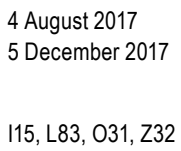

The health tourism market has high susceptibility to innovation. This is due to the functioning of not only tourism enterprises on this market, but above all the providers of medical services. This market is characterized by high development dynamics. The services are provided at all market levels from local, through regional, national to global. The objective of this study is to identify the entities of the health tourism market which are responsible for introducing innovative offers on that market. Firstly, the theoretical issues are described concerning tourism market innovations and the structure of the health tourism market. This enabled the identification of the areas of innovation on the health tourism market. The conducted research is conceptual.

\section{Introduction}

Innovations are a key instrument for the development of the tourism market structure. The health tourism market is particularly affected by innovation. It is a result of highly dynamic development of this market on a global level but also of the engagement of many entity groups who are participants of that market. Apart from tourism market entities, medical market entities have a decisive role in terms of implementing innovative solutions. Health 
tourist destinations play a significant role in the adoption of innovations on the health tourism market as they develop territorial products of health tourism, including: medical, health resort, spa \& wellness and aesthetic medicine tourisms.

The objective of this study is to identify the entities of the health tourism market which are responsible for introducing innovative offers on that market. Firstly, the theoretical issues are described concerning tourism market innovations and the structure of the health tourism market. This enabled the identification of the areas of innovation on the health tourism market. The conducted research is conceptual. The following research methods were applied: a critical analysis of sources, logical and heuristic operations.

\section{Innovations on the tourism market}

Innovations are an important factor for shaping and developing modern markets. According to traditional views on the notion of innovation formulated by J. Schumpeter (1960) in relation to the functioning of the market, the term innovation means a combination of the following factors, with their functional interdependencies:

- launching new products or improving existing ones,

- implementing new or improved production technology, including new methods of providing services,

- introducing new ways of selling and buying, including new ways of creating interaction with customers, together with appropriate customer care systems,

- opening a new market, both in terms of supply, production or sales,

- using new raw materials, materials and tools,

- implementing changes in the organization of production, including changes in the organization of the service providing process (Niedzielski, 2008, pp. 230-232).

Innovations are one of the key elements of increasing competitiveness and achieving market success in the knowledge-based economy. When taken in a general view, one may regard innovation as a process of introducing new products, ideas or way of acting. Thus, these would include all positive implemented changes which are perceived as new from the perspective of the entity that introduced them (Kalinowski, 2010, pp. 13-18). Innovations are connected with creating new market offers. However, normally these are not completely new products but rather improvements of already existing products (Westland, 2008, pp. 42-43), which are given new practical values or increased quality parameters. Thus, the vast majority of innovations consists in creative imitation of already existing solutions. Creative imitation focuses particularly on the consumer needs and starts not from observing the product but the market (Drucker, 2000, pp. 254-255).

Typical innovative undertakings in terms of services include:

- creating new service concepts,

- new forms of cooperation with the client,

- new systems for providing services,

- using modern IT solutions (Den Hertog, 2002, pp. 226-231).

The following types of innovation can be distinguished as a result of introducing new concepts for business operation on the market:

- product,

- process,

- organizational (managerial), 
- marketing (Niedzielski, 2013, p. 29),

- institutional (Hjalager, 2010, pp. 1-12).

Similarly, as on any other markets, innovation plays a key role on the tourism market in achieving sustained competitive advantage by entities from the supply side of the market (Szymańska, 2013, pp. 146-148). The ongoing globalization processes demand not only increased innovation activity from tourism enterprises but also from tourist destinations as it determines their survival and further growth and development. Business operation of entities on the tourism market imposes the necessity to develop different types of innovations complementarily (Gołembski, 2007), as tourism enterprises (mainly micro, small and medium) vary in terms of their level of innovation, which, among other things, depends on the business strategy used, type of business, staff qualifications and market environment (Gancarczyk, 2012, p. 105).

Tourism enterprises have a decisive role in the development of tourism market innovation. The innovation of tourism enterprises is determined by independent actions of these entities but also by sources of innovation that come from: suppliers, competitors, employees, consumers (Peters, Pikkematt, 2005), advisory and consultancy firms (Wszendybył-Skulska, 2010, p. 622), tourism policy entities. The actions of tourism policy entities may be a source of innovation for tourism entities as they develop pro-innovation policies aimed at the tourism market, in particular at tourism entrepreneurs. Furthermore, tourism policy entities may conduct innovative actions on their own. It should be noted that one of the main means of introducing innovation to the operations of tourism market entities is modern information technologies (Prahalad, Krishnan, 2010, p. 15).

Innovation processes on the tourism market are also a result of the actions undertaken by tourist destinations (Panasiuk, 2013a, pp. 267-277). They are directly connected to the public system (local authorities) and implement tasks related to the tourism policy. The entities representing public authorities impact innovation through developing a network of connections between entrepreneurs and tourism organizations from an area which has tourism values and attractions, tourism infrastructure and where tourism services are provided. The public entities' role in a tourism area is to establish an optimal, under specific circumstances, configuration of competitive advantages (Jaremen, Rapacz, Gryszel, 2010, p. 166) and as a result to implement an innovation policy. The main goal of innovation policy on the tourism market should involve the state's influence on the structure of that market through strategic actions. The innovation issues can be found in strategic documents as priorities and actions with a defined funding scheme, but in practice they are mainly funded through the European Union's structural funds (Panasiuk, 2014a).

Innovations lead to the development of a new tourism market, mainly with respect to quality, which decides on the market position of the providers of that market and satisfies the needs of consumers-tourists to a greater extent. Thus, innovations directly affect the market structure and drive the market development both in terms of offer creation and consumption (Panasiuk, 2014b, pp. 246-247).

\section{Health tourism mapket}

One of the tourism markets is the health tourism market. This market is determined by reasons for tourism, i.e. trips which main or complementary aim is to improve health and physical and mental condition of a tourism participant. The health tourism market is also a special industry encompassing in its activities elements of other tourism industries, mainly the hotel industry, however, with an equal involvement of medical industries, i.e. medical treatment, including wellness. 
A special nature of health tourism mainly results from an aim of and reason for a trip to destinations where medical services are offered and to health resorts as well as from needs to use services provided by these enterprises.

The main reasons for health tourism include:

a) with respect to medical tourism, including aesthetic medicine:

- receiving medical treatment, often one that includes invasive procedures,

- receiving planned medical procedures, including dentistry,

b) with respect to health resort (Gaworecki, 2000, p. 36) and spa \& wellness tourisms:

- renewal of vital strength, as a result of staying in a particular tourist destination,

- improvement of health and well-being,

- active leisure.

Defining health tourism as all relationships, activities and phenomena which result from stays of people having medical treatment, including spa treatment, and from travels to medical tourist destinations and health resorts and returns to their places of living (Kaspar, Ferlich, 1979; Kornak, 1999, p. 21) constitute the grounds to identify the essence of health tourism and, next, to indicate its elements of the subjective and objective structure. In objective terms, the health tourism market is a process in which customers (tourists, patients, spa guests) and service providers (providers of tourism and medical services as well as health and wellness/medical tourist destinations and health resorts) specify the subject of the market exchange which constitutes tourism and medical (health resort) services offered at defined prices and conditions (Panasiuk, 2013b, pp. 9-22).

The main entities operating on the health tourism market are in terms of supply (Szymańska, Dziedzic, Panasiuk, Panfiluk, Rutkowski, 2017, pp. 80-90):

- enterprises providing medical services (hospitals, plastic surgery clinics, treatment centres, clinics and analytical laboratories),

- health resort enterprises (health resort treatment facilities, e.g. sanatoriums, natural healing facilities),

- entities providing spa \& wellness services, both hotel businesses as well as entities for which these services are their core business,

- tourism enterprises operating in a tourist destination and offering their services both to health tourists and other tourists (incl. hotel, catering, transport, inbound tourism movement travel agencies, tourist attractions),

- specialized tourism enterprises operating in tourism areas, tourism organizers servicing the health tourism segment, intermediaries and tourism agents selling comprehensive packages or focused solely on brokerage and service in terms of medical services,

- enterprises offering health tourists, including spa guests, para-tourism services which main function is to satisfy needs of permanent inhabitants of health tourist destinations, including health resorts.

It should be noted that the health tourism market can be developed mainly thanks to the supply elements of the general tourism market. It is complemented by elements relevant to the reasons for health tourism related to the medical offer, that is by those resulting mainly from activities of medical facilities sanatoriums or health resort hospitals but also supported by the activities of local authority bodies in tourist destinations.

When referring to the analysis of the health market structure from the objective perspective, one should mention the following patterns related to: 
- demand for health tourism services,

- supply of health tourism services,

- instrumental scope of influence on that market by public bodies.

The demand for the health tourism offer can be classified from an objective point of view taking account of group of patients, especially in terms of financing methods and a choice of places where health services are consumed. These are tourists (including patients, health resort tourists) (Szromek, 2012, pp. 188-190) using:

- medical offers (also in health resorts) in health tourist destinations, incurring costs on their own and choosing a place and service providers independently,

- medical offers financed by a health insurance purchased independently (Cohen, 2012, pp. 9-20),

- offers of health resort tourism funded or partially funded by social insurance thanks to which patients have a possibility of a limited choice of places and dates of a stay as they are referred to a health resort on the basis of a doctor's referral.

Health tourism supply demonstrates slightly different features than tourism supply in a broad sense. The expansion of current medical tourism influences the global economy significantly. The most essential issue is the difference in production capacity and costs of services between developed countries (e.g. the USA, Germany, the UK) and developing ones (e.g. Mexico, Brazil or Central and Eastern European countries). The greatest mobilization of health tourism offer can be observed in developing countries where entities of this market try to fully exploit financial and human capital of this industry and, at the same time, also receive support from the government.

The characteristic features of medical tourism supply include:

- considerable dependence of the supply structure on demand,

- high qualifications of a personnel servicing health resort tourists,

- high availability of information on the offer (especially online),

- high-quality services and management system of health resort tourists,

- a great complementary character of supply of medical and tourism services,

- progressive liberalization of regulations facilitating free international movement of tourists and use of health services,

- high capital intensity,

- very low level of seasonality (Rab-Przybyłowicz, 2014, pp. 38-41).

Supply of the health tourism market includes medical and tourism services which may be the subject of the market exchange as separate services or in the form of a package. Offers are developed by entities of the medical industry, tourism industry and comprehensively by health tourist destinations. The discussion on these issues will be continued in the next subchapter.

A special role on the tourism market is played by public entities which implement tourism policy. In these deliberations, these are also public entities responsible for social health protection policy. Every country has its own legal regulations concerning a healthcare system and the availability of the system for their own citizens as well as rules of financing from public and/or private sources. Additionally, the scope of specific medical services which can be provided in particular countries as well as those which are illegal due to ethical or religious reasons should be listed. 


\section{Identification of innovation areas on the healih tourism market}

The analysis conducted on the health tourism market structure showed that it is the market which is welldeveloped in terms of offer as well as entities creating it and the market participants representing the demand side and demonstrating various reasons for using health tourism services. This market is very competitive at all levels, from the global, through the continental and to the national and regional ones.

It is significant to stress that the elements of the health tourism market structure adopt innovations. In this respect, the most essential role is played by entities of the supply side of this market and the offer developed by them in terms of health tourism. The following entities should be mentioned in particular:

- medical market entities (e.g. hospitals, sanatoriums, spa \& wellness centres),

- tourism market entities (e.g. hotels),

- specialized entities of the health tourism market (i.e. tour operators creating health tourism offers and travel agents) that combine elements of medical and tourism services into an integrated package,

- health tourist destinations, together with health resorts (countries, regions, cities and smaller towns), which, in order to promote health tourism offers of their areas, should search for original solutions, for example those combining medical services provided by commercial entities with original tourism-oriented offers.

Moreover, a health tourism product has a direct influence on developing innovations in the health tourism market. This definition encompasses all goods and services which can be purchased in health tourist destinations, including health resorts, enable tourists (patients, spa guests) to arrive and stay there (tourism services), and use health services (medical services) (Krasiński, 2001, p. 29).

A health tourism product is diverse depending on the scope of resources and services available in a tourism area and functioning of submarkets: the medical tourism, health resort tourism, spa \& wellness tourism, aesthetic medicine tourism markets. Theoretically, it can take a comprehensive structure, however, in market practice, such a product should be analysed separately for specific types of offers, i.e. a product of (Szymańska et al., 2017, pp. 93-96):

- medical tourism,

- health resort tourism,

- spa \& wellness tourism,

- aesthetic medicine tourism.

In the structure of all of the listed product types, there are common elements resulting from tourism area potential and connected with service of every tourism form, that is tourism values (natural and cultural), tourism base (accommodation, catering, transport, additional ones) and typical tourism services. Elements connected with particular types of a health tourism product result mainly from resources and services of a medical nature. These are specialist elements of given product types. Their diversification concerns especially services provided to health tourists, but also elements of tourism facilities and values.

A health tourism product or, in fact, partial products of medical, health resort, spa \& wellness as well as aesthetic medicine tourisms are a fundamental subject of influence of health tourism entities in terms of developing innovations. Innovations can concern not only direct product-related aspects, but also organizational (means of servicing health tourists), marketing (means of addressing an offer to groups of consumers) or institutional which is essential when building partnership in health tourism areas between entities offering services. 


\section{Conclusion}

The issue of innovations in the health tourism market concerns especially supply aspects as it is mainly connected with natural resources and capital resources, including infrastructural, human, informational and technological ones. These issues chiefly concern a size and structure of tourism movement, especially anticipation of needs of tourists who present their future expectations in terms of health tourism in tourism reception areas. Thanks to innovations, a new health tourism market, mainly in terms of quality, is created and it determines a market position of the market providers as well as better satisfies needs of consumers, i.e. tourists and patients. Therefore, innovations directly influence the structure of this market and are the driving force of development from the point of view of offer creation as well as consumption.

\section{References}

Cohen, G. (2012). How to regulate medical tourism (and why it matters for bioethics). Developing World Bioethics, 1 (12).

Den Hertog, P. (2002). Co-producers of innovation: on the role of knowledge-intensive business services in innovation. In: J. Gadrey, E. Gallouj, E. Elgar (eds.), Productivity, innovation and knowledge in services. MA, Cheltenham-Northampton: New economic and socio-economic approaches.

Drucker, P. (2000). Myśli przewodnie Druckera. Warszawa: MT Biznes.

Gancarczyk, J. (2012). Innowacje w małych i średnich przedsiębiorstwach turystycznych. Ekonomiczne Problemy Usług, 91.

Gaworecki, W.W. (2000). Turystyka. Warszawa: PWE.

Gołembski, G. (ed.) (2007). Przedsiębiorstwo turystyczne. Ujęcie statyczne i dynamiczne. Warszawa: PWE.

Hjalager, A-M. (2010). A review of innovation research in tourism. Tourism Management, 1 (31).

Jaremen, D.E., Rapacz, A., Gryszel, P. (2010). Innowacje a atrakcyjność turystyczna wybranych miejscowości sudeckich. Acta Scientairum Polonorum, Oeconomia, 9 (4).

Kalinowski, T.B. (2010). Innowacyjność przedsiębiorstw a systemy zarządzania jakością. Warszawa: Oficyna.

Kaspar, C., Ferlich, F. (1979). Marketing Konzeption der Heilböund Kurorte B16. Hochschule St. Gallen.

Kornak, A.S. (1999). Uzdrowiska polskie w systemie rynku i zarządzania marketingowego. Bydgoszcz: Kujawsko-Pomorskie Studium Edukacyjne.

Krasiński, Z. (2001). Rynek usług uzdrowiskowych w Polsce. Poznań: Wyższa Szkoła Zarządzania i Bankowości.

Niedzielski, P. (2013). Kreatywność i procesy innowacyjne na rynku usług transportowych. Ujęcie modelowe. Szczecin: PTE.

Niedzielski, P. (2008). Zarządzanie innowacjami w przedsiębiorstwach usługowych. In: B. Filipiak, A. Panasiuk (ed.), Przedsiębiorstwo usługowe. Zarządzanie. Warszawa: Wydawnictwo Naukowe PWN.

Panasiuk, A. (2013a). European Union funds in the development of region al sustainable tourism economy in 2007-2013. 2nd International Scientific Conference Tourism in Southern and Eastern Europe 2013. Opatija: University of Rijeka.

Panasiuk, A. (2013b). Miejsce turystyki uzdrowiskowej w strukturze rynku turystycznego. Ekonomiczne Problemy Turystyki, 3 (23).

Panasiuk, A. (ed.) (2014a). Fundusze Unii Europejskiej w gospodarce turystycznej. Warszawa, Difin.

Panasiuk, A. (2014b). Rynek turystyczny. Studium strukturalne. Warszawa: Difin.

Peters, M., Pikkematt, B. (eds.) (2005). Innovation in hospitality and tourism. New York: Routledge.

Prahalad, C.K., Krishnan, M.S. (2010). Nowa era innowacji. Warszawa: Wydawnictwa Profesjonalne PWN.

Rab-Przybyłowicz, J. (2014). Produkt turystyki medycznej. Warszawa: Difin.

Schumpeter, J. (1960). Teoria rozwoju gospodarczego. Warszawa: PWN.

Szromek, A.R. (2012). Wskaźniki funkcji turystycznej. Koncepcja wskaźnika funkcji turystycznej i uzdrowiskowej. Gliwice: Wydawnictwo Politechniki Śląskiej.

Szymańska, E. (2013). Procesy innowacyjne przedsiębiorstw świadczących usługi w zakresie organizacji imprez turystycznych. Białystok: Oficyna Wydawnicza Politechniki Białostockiej. 
Szymańska, E., Dziedzic, E., Panasiuk, A., Panfiluk, G., Rutkowski, M. (2017). Innowcje w turystyce zdrowotnej. Waraszawa: Difin. Westland, J. (2008). Global innovation management. A strategic approach. New York: Palgrave.

Wszendybył-Skulska, W. (2010). Żródła innowacyjności w turystyce. Acta Scientiarum Oeconomia, 9 (4).

Cite this article aS: Panasiuk, A. (2018). Theoretical aspects of innovation in health Tourism. European Journal of Service Management, 1 (25), 213-220. DOI: 10.18276/ejsm.2018.25-26. 